\title{
"Do czego się było przyznawać, jak nie istniał homoseksualizm?" Różowy język w narracjach pamięci o męskiej homoseksualności w PRL
}

\author{
Jędrzej Burszta \\ Uniwersytet Warszawski
}

\begin{abstract}
Artykut oparty jest na materiale badawczym zebranym w ramach wywiadów etnograficznych (jakościowych, biograficznych) przeprowadzonych w ramach międzynarodowego projektu CRUSEV. Autor przedstawia analize fragmentów zebranych wywiadów pod kątem języka, jakim posługuja się rozmówcy, aby odtworzyć swoje wspomnienia z okresu PRL, kiedy homoseksualność stanowiła temat tabu nieporuszany w debacie publicznej. Opierając się na analizie wybranych wypowiedzi, autor skupia się na kilku wybranych kwestiach: samoidentyfikacji rozmówców, kwestii coming outu przed rodziną oraz specyficznego "żargonu" czy też "różowego języka" używanego w społecznościach homoseksualnych w dużych miastach Polski. Autor dowodzi, że sposób budowania narracji o swoim życiu (m.in. aluzyjność, żartobliwość języka) ujawnia nie tylko specyfikę homoseksualnego życia w PRL, ale w równej mierze pokazuje odmienne strategie konstruowania przedemancypacyjnej tożsamości gejowskiej.
\end{abstract}

Stowa kluczowe: homoseksualność, oral history, biografia, pamięć, język

Język peerelowskiej homoseksualności przedarł się do społecznej świadomości za sprawą kultowej powieści Lubiewo Michała Witkowskiego (2004), niezaprzeczalnie najważniejszej reprezentantki polskiej współczesnej literatury gejowskiej. Ironiczno-nostalgiczna i błyskotliwie kampowa opowieść o perypetiach żyjących za komuny "ciotek" spopularyzowała tym samym "ciotowski" slang: umiejętnie przetworzoną przez literacką wyobraźnię Witkowskiego rekonstrukcję "przegiętego" języka, jakim posługiwać się mieli członkowie (członkinie) „subkultury ciotowskiej” żyjący w cieniu siermiężnej i seksualnie regresywnej Polskiej Republiki Ludowej. Zarazem jednak przedstawiona w Lubiewie narracja o męskiej nieheteronormatywnej seksualności pozostaje - zgodnie zresztą z intencją autora tyleż zwierciadłem owej przemilczanej „dewiacyjnej” historii polskich homoseksualistów, co obrazem fascynacji Witkowskiego figurą przedemancypacyjnej "cioty", przegiętego homo sovieticus ustawionego w opozycji wobec figury nowoczesnego "geja" będącego "wytworem późnej fazy liberalnego, konsumpcyjnego kapitalizmu w Stanach Zjednoczonych i Europie Zachodniej" (Witkowski 2014: 397). Oddając głos starym "ciotkom" tęskniącym za utraconą młodością - i przetwarzając ten głos - Witkowski zabarwił swoją powieść specyficznym rodzajem nostalgii, czuło i prześmiewczo portretując swoje bohaterki jako relikty nie tyle nawet minionego systemu politycznego, ile osoby reprezentujące inny paradygmat "prywatnej" homoseksualności, nieafiszujące się publicznie ze swoją orientacją i krytyczne wobec potransformacyjnego, emancypacyjnego dyskursu LGBTQ ${ }^{1}$

1 Powołuję się tu na zaproponowaną przez Błażeja Warkockiego (2014) periodyzację dzielącą historię nienormatywnej emancypacji w Polsce na trzy fale: 1981-1989 (wczesna faza, homoseksualiści jako "inni”), 1990-2003 (emancypacja tożsamościowa gejów i lesbijek) i 2003-dziś (m.in. upolitycznienie dyskursów seksualności, zwiększona widzialność w

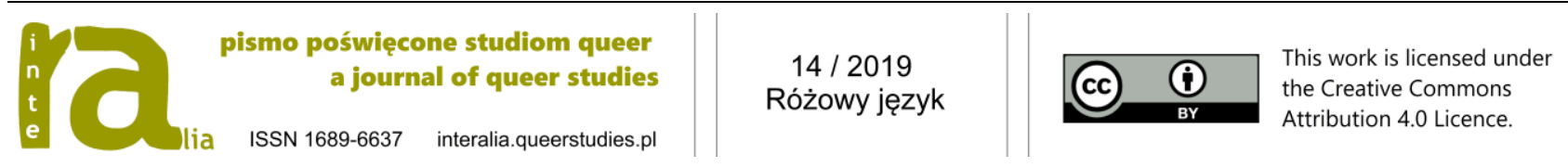


W niniejszym artykule pragnę przyjrzeć się językowi peerelowskiej męskiej homoseksualności, rezygnując jednak zarówno z nostalgizującej, jak i romantyzującej perspektywy eksplorowanej w literaturze pięknej. Przedmiotem analizy jest żywy język grupy homoseksualnych mężczyzn - zebrane w toku pracy w projekcie badawczym Cruising the 1970s: Unearthing Pre-HIV/AIDS Sexual Cultures relacje historii mówionej o codziennym życiu nieheteronormatywnych mężczyzn w okresie $P R L$, ze szczególnym uwzględnieniem lat 1970-1985. Zebrany przeze mnie materiał prezentuje zaledwie skromny wycinek z szerszej, wielowątkowej historii nienormatywnych seksualności w PRL, siłą rzeczy fragmentaryczny, niekompletny oraz - co należy szczególnie podkreślić - reprezentujący jedynie głos ściśle określonej grupy osób. Wszyscy moi rozmówcy to homoseksualni mężczyźni, w większości urodzeni w latach 50., którzy w latach 70. mieszkali w dużych miastach (Warszawa, Poznań, Wrocław). Przeważająca większość ma wykształcenie wyższe ${ }^{2}$. Niezależnie od indywidualnych różnic w postrzeganiu kwestii orientacji czy tożsamości seksualnej - do czego powrócę w dalszej części artykułu wszyscy aktywnie uczestniczyli w życiu gejowskim w PRL, przynależąc do różnych homoseksualnych społeczności i grup towarzyskich, wchodząc w intymne relacje z mężczyznami i generalnie identyfikując się jako osoby homoseksualne i poczuwając się do bycia reprezentantami pokolenia przedemancypacyjnego, wyraźnie przez nich rozgraniczanego od dzisiejszej polityki i aktywizmu LGBTQ. Z powodu nieodzownego ograniczenia uzyskanego w ten sposób wglądu w prywatne historie homoseksualności w PRL, grupę badanych homoseksualnych mężczyzn postrzegam raczej jako specyficzną subkulturę czy też członków kultury alternatywnej, aniżeli jako mniejszość seksualną czy kulturową (zob. Lis 2015: 35, 38-41; Nowak 2016: 182). Tym samym, analizowane tu narracje dotyczą wyłącznie wspomnień osób, które akceptowały swoją odmienność, i pomimo różnych indywidualnych trudności prowadziły udane "życie gejowskie" - nie uwzględniają zatem m.in. głosów tych mężczyzn, którzy nie mogli sobie pozwolić w tym okresie ani na przynależność do społeczności gejowskiej, ani na wchodzenie w relacje intymne z partnerami tej samej płci.

Dla pozyskanego w ramach badań i poddanego tu analizie materiału istotne znaczenie ma kontekst metodologiczny - sytuacja wywiadu etnograficznego, w szczególności skupionego na historii mówionej odsłaniającej indywidualne spojrzenia na historię nienormatywnych seksualności. W każdym przypadku zgoda na rozmowę o przeszłości stanowi zarazem zaproszenie do wspólnego doświadczenia tego, jak indywidualna pamięć rejestruje, odtwarza i (re)konstruuje wyobrażenia o minionym czasie. To każdorazowo podejmowana próba dotarcia do prywatnej „prawdy” o epoce, w której temat

przestrzeni publicznej i backlash homofobiczny). Dla przedstawionego w niniejszym tekście wywodu szczególnie istotne jest wskazanie przez Warkockiego roku 1981 jako punktu otwierającego polityczną emancypację ruchów homoseksualnych, jako że analizowane przeze mnie narracje dotyczą w znacznej mierze lat siedemdziesiątych, a więc okresu przedemancypacyjnego.

${ }^{2}$ Najstarszy mężczyzna urodził się w 1936 roku, a najmłodszy w 1959 roku. Przeważająca większość to roczniki urodzone w latach pięćdziesiątych. W ramach przyjętej metodologii badawczej oraz założeń samego projektu CRUSEV, zależało mi na dotarciu do nieheteronormatywnych osób, które w interesującym mnie okresie (1970-1985) były już albo osobami dorosłymi, albo dojrzewającymi. Na analizowany w tym artykule materiał badawczy składa się 11 wywiadów etnograficznych przeprowadzonych przeze mnie w okresie sierpień 2017 - czerwiec 2018. Dodatkowo, wykorzystuję również wybrane fragmenty z wywiadów przeprowadzonych przez innych członków zespołu badawczego: Tomasza Basiuka, Karolinę Morawską i Krzysztofa Zabłockiego. 
homoseksualności - a co za tym idzie, doświadczenie codziennego życia jako osoba nieheteronormatywna - nie funkcjonował w dyskursie publicznym, nie licząc sporadycznych wzmianek w prasie (Zob. Kurpios 2003; Biedroń 2010: 67-72; Szulc 2018: 97-100). Jak w książce Gejerel podsumowuje Krzysztof Tomasik, "liberalne prawo PRL-u, w istocie niedostrzegające homoseksualności, sprawiało, że preferencje seksualne były prywatyzowane, i to od indywidualnej sytuacji danej osoby zależało jej poczucie wykluczenia i dyskryminacji" (Tomasik 2012: 19). Prywatyzacja homoseksualności wyraźnie zaznacza się również w języku, jakim posługują się moi rozmówcy, opowiadając o swoich wspomnieniach. Brak opracowań historycznych, które porządkowałyby historię/ie homoseksualności w Polsce Ludowej oznacza również, że nie istnieje żadna dominująca narracja - a w rezultacie, nie ma zgody co do tego, jak może, a jak nie powinna brzmieć opowieść o tym okresie. Tym samym, zebrany przeze mnie materiał siłą rzeczy jest przefiltrowany przez i silnie uwarunkowany indywidualnym (a często niepowtarzalnym) stylem mówienia danej osoby, prywatnymi idiosynkrazjami, przyzwyczajeniami, „żargonem” typowym dla określonego środowiska (np. wpływy regionalizmów), ale - właśnie dlatego, że jest to wywiad ukierunkowany na przeszłość - w równej mierze rozpięty jest pomiędzy próbą odtworzenia językowego świata tamtej epoki, a poleganiem na języku dzisiejszym.

Uzyskany przeze mnie materiał badawczy odsłania ogromne bogactwo i różnorodność doświadczeń i opowieści o "queerowych kulturach" PRL. Poniższy artykuł skupia się przede wszystkim na próbie zrekonstruowania kilku wybranych aspektów najczęściej powtarzających się w indywidualnych narracjach, za punkt wyjścia uznając pytanie o to, jakim językiem posługują się moi rozmówcy, chcąc opowiedzieć o przeszłości. Opierając się na analizie wybranych fragmentów ich relacji, skupiam się na kilku wybranych kwestiach: samoidentyfikacji rozmówców, a więc refleksji nad tym, w jaki sposób i przy użyciu jakich określeń czy kategorii tożsamościowych budują oni narrację o "odkrywaniu" swojej odmienności seksualnej; relacji z najbliższą rodziną i formach funkcjonowania wobec "niewypowiedzianej" prawdy o homoseksualności; charakterystycznych cechach "żargonu” peerelowskich społeczności homoseksualnych, jego aluzyjności, żartobliwości i subwersywnego potencjału. W podsumowaniu proponuję kilka uwag o charakterze ogólnym, odnoszących się do wspólnych cech wyróżniających w moim odczuciu przedstawione w artykule prywatne narracje o homoseksualności, oferujących być może wgląd w skomplikowane procesy tożsamościowe i znaczące "pęknięcia" we wciąż konstruowanym dyskursie historiografii polskiej homoseksualności.

\section{„PRL nie zakładał, że ktoś może być homo”. Samoidentyfikacja a niewidoczność homoseksualności}

Pytanie o samoidentyfikację rozmówców nierozerwalnie związane jest z odniesieniem do wspomnień z dzieciństwa i wczesnych lat młodości, a więc okresu, w którym negocjowali oni swoją tożsamość seksualną czy seksualne pragnienia. Pytanie o najwcześniejsze wspomnienia związane z poczuciem „ ¿inności” czy „odmieńczości” - jeszcze nienazwaną sferę doświadczenia, ani tym bardziej niezwiązaną z wyrazistymi kategoriami tożsamościowymi - wydawało mi się kluczowe dla próby zrozumienia trajektorii indywidualnych narracji o nienormatywnych życiu w PRL-u. Chociaż moi rozmówcy pochodzą z różnych regionów kraju, i wychowali się zarówno w dużych miastach, jak i na wsi oraz w 
mniejszych miejscowościach, wszyscy stanowczo podkreślali, że nie mieli problemów z akceptacją odkrywanego w młodości pożądania do osób tej samej płci:

[...] to u mnie to się wszystko stało tak bardzo naturalnie, spokojnie, bez jakichś tam wstrząsów, "Boże, co się ze mną dzieje, dlaczego jestem taki a nie inny"? (mężczyzna, 60 lat, Warszawa, wykształcenie wyższe).

Także czułem zawsze, że to jest kierunek mojego zainteresowania, wiesz, bo po prostu od zawsze, nie tam że ktoś mi wmówił albo coś (mężczyzna, 73 lata, Poznań, wykształcenie wyższe).

Dla mnie to było całkiem normalne. Jestem taki jaki jestem, ja siebie kocham, akceptuję, lubię siebie takiego, nikomu krzywdy tym nie robię, nie afiszuję się też, żeby innym zgorszenia nie dać. A mam z tego jakąś przyjemność, radość, jestem szczęśliwy. Dla mnie to było najważniejsze. I żeby druga strona też była zadowolona (mężczyzna, 59 lat, Poznań, wykształcenie średnie).

Proces odkrywania - oraz równolegle postępujący proces akceptacji - własnej homoseksualności opisywany jest przy użyciu języka wskazującego na "instynktowność", "naturalność", "normalność" pragnienia i pożądania osób tej samej płci. Są to prawie zawsze historie opowiadające o pierwszych zauroczeniach i bliskich kontaktach emocjonalnych z rówieśnikami, o budzącej się fascynacji męską urodą i cielesnością (np. epizody podglądania kolegów przebierających się w szatni, dorosłych mężczyzn opalających się nad jeziorem itp.), o odkrywaniu pożądania skierowanego do osób tej samej płci i o pierwszych erotycznych przygodach i podbojach. Co istotne, te indywidualne opowieści o kształtowaniu się seksualności - rekonstruowane w pamięci w momencie etnograficznego spotkania - wyrażane są za pomocą języka, który odnosi się prawie wyłącznie do sfery seksualnej. Odkrywanie homoseksualności oznaczało w pierwszej kolejności uświadomienie sobie innego „ukierunkowania” czy też "zorientowania” na mężczyzn ("chłopak zorientowany"), a więc wiązało się z ekspresją seksualnego pragnienia do osób tej samej płci, a nie konstytuowania się tożsamości homoseksualnej. Dorastając w latach 60. i 70., moi rozmówcy (niezależnie od miejsca zamieszkania) prawie nigdy nie posiadali na tym etapie życia jakiejkolwiek wiedzy o istnieniu zjawiska nazywanego homoseksualizmem. Podkreślanie "naturalności" odkrywanych pragnień stanowi tym samym wyraz przekonania o tym, że orientacja homoseksualna jest czymś odczuwanym instynktownie, podobnie jak heteroseksualność, a więc czymś, z czym człowiek się rodzi, a nie do czego może zostać przyuczonym, przekonanym albo zmuszonym.

Przekonanie o biologicznej genezie homoseksualnych preferencji często idzie w parze z podkreślaniem łatwości, z jaką moi rozmówcy akceptowali swoją orientację jako „normalną". W poniższym fragmencie rozmówca łączy ze sobą refleksję o kształtowaniu się tożsamości seksualnej z różno- 
rodnymi doświadczeniami erotycznymi (zarówno z mężczyznami, jak i kobietami), które jednak w żadnym stopniu nie wywoływały u niego konfuzji co do tego, kim jest:

Nigdy nie miałem problemów z własną tożsamością w sensie tego, że miałem jakieś kompleksy z tego powodu, że jestem gejem, czy tego... Dla mnie to była sprawa zupełnie naturalna, chociaż zdarzyło się, że w czasie studiów miałem kontakty z dziewczynami. [...] W każdym bądź razie te kontakty [z kobietami - przyp. JB] były i nie powiedziałbym, żebym z tego powodu odczuwał jakieś rozterki czy zastanawiania się, czy iść tu w tą stronę, czy w tą stronę. To było dla mnie zupełnie naturalne i nie widziałem żadnego problemu (mężczyzna, 73 lata, Poznań, wykształcenie wyższe).

Interesująca wydaje się uwaga rozmówcy, że pomimo przeżytych doświadczeń erotycznych z partnerami obojga płci, nie zastanawiał się on „czy iść tu w tą, czy w tą stronę". Co istotne, w dalszej części wywiadu rozmówca stanowczo oponował przed uznaniem go za osobę biseksualną, kontakty seksualne z kobietami sprowadzając zaledwie do mało znaczącego epizodu w życiu, tłumacząc je młodzieńczą fazą eksperymentowania z seksualnością, w żadnym wypadku jednak nie przekreślającej identyfikacji jako osoby homoseksualnej ${ }^{3}$.

Dla niektórych rozmówców ważnym punktem odniesienia jest porównanie z młodszym pokoleniem gejów dorastających już po transformacji ustrojowej:

Przede wszystkim, że nigdy, w przeciwieństwie do wielu młodzieńców, nawet w dzisiejszych czasach, nigdy nie miałem żadnych wątpliwości co do tego, że jestem taki, a nie inny. Wiedziałem, że po prostu taki się urodziłem, taki jestem, takim pozostanę, prawda? (mężczyzna, 72 lata, Paryż, wykształcenie wyższe).

Zwrócenie uwagi na różnicę pomiędzy współczesnym dyskursem tożsamościowym LGBTQ a doświadczeniem pokolenia żyjącego w PRL-u wydaje się służyć przede wszystkim podkreśleniu niezmienności seksualnych preferencji. Homoseksualna orientacja nie jest zatem postrzegana przez nich jako wybór czy świadoma decyzja, ale jest czymś, co odkrywa się w sobie i należy po prostu zaakceptować to, że "takim jestem, takim pozostanę". W tym sensie, pomimo wyraźnego oporu stawianego emancypacyjnym modelom tożsamości gejowskiej (do czego powracam w dalszej części artykułu), rozmówcy formułują esencjalizujący model orientacji seksualnej będącej stabilnym „ukie-

\footnotetext{
${ }^{3}$ Niektórzy moi rozmówcy równolegle funkcjonowali w relacjach heteroseksualnych - żenili się i mieli dzieci, prowadząc „podwójne życie”. Decyzja o małżeństwie zazwyczaj powodowana była naciskiem ze strony najbliższego otoczenia, albo rozumiana była jako "naturalny" krok na drodze życiowej, niekwestionowany m.in. z powodu braku istnienia innych niż heteronormatywny wzorców życiowych. W każdym przypadku małżeństwo prędzej czy później kończyło się rozwodem. Większość jednak wchodziła w dłuższe związki wyłącznie z mężczyznami.
} 
runkowaniem" ku pożądaniu osób tej samej płci. Homoseksualność jest „prawdą” o sobie; naturalnym pragnieniem, któremu nie można stawiać oporu.

Nieobecność tematu homoseksualności w dyskursie publicznym PRL - w prasie, telewizji, w programie edukacji szkolnej (zob. np. Morawska w tym numerze) - dla osób nieheteronormatywnych oznaczała zazwyczaj, że pragnąc pozyskać jakąkolwiek wiedzę o budzących się pragnieniach seksualnych, byli skazani na indywidualny wysiłek. Z dzisiejszej perspektywy rozmówcy czasem tłumaczą społeczną tabuizację tej sfery życia ideologiczną wykładnią państwa socjalistycznego, zgodnie z wyrażonym w tytule tego artykułu stwierdzeniem, że w Polsce Ludowej „nie istniał homoseksualizm”:

Wychowania do życia w rodzinie, to czegoś takiego nie było. Było wychowanie obywatelskie, ale nie, nie. Na te tematy w ogóle nie było żadnych dyskusji. Bo to była komuna, za czasów komuny nie było narkomanii, pijaństwa, i tego typu orientacji, no nie. Ale był z kolei jakiś większy chyba nacisk na jakiś humanizm, bo po prostu te rzeczy były traktowane chyba bardziej normalnie jak w dzisiejszych czasach. [...] No jakoś tak normalnie, no po prostu, nie rozmawiało się. Było naturalne, że ktoś $w$ tej klasie czy gdzieś indziej jest taki a nie inny, przechodziło się do porządku dziennego. Nie było żadnego szykanowania, nigdy się z tym nie spotkałem, że jakieś wytykanie palcem, a tu to czy tamto, nie, nie (mężczyzna, 60 lat, Warszawa, wykształcenie średnie).

Rozmówca w dość ironicznym tonie zestawia ze sobą zachowania patologiczne takie jak narkomania i alkoholizm z "tego typu orientacjami", lokując homoseksualność w obrębie negatywnych zjawisk społecznych, które stały w sprzeczności z wyobrażeniem o powinnościach i cechach obywateli wyrażanym przez propagandę komunistyczną. Wskazuje tym samym, że dość powszechne w tym okresie wiązanie społeczności homoseksualnych z kręgami przestępczymi - naczelny argument wysuwany przez milicję, mający później służyć usprawiedliwieniu akcji "Hiacynt” (Tomasik 2012: 39-44) - było po części rezultatem wyparcia tego tematu z debaty publicznej. W podobnym tonie wypowiada się w swoich wspomnieniach Michał Głowiński, opisując towarzyszącą mu w młodości samotność i poczucie całkowitego wyobcowania: „Obowiązywała pełna pruderia, niejako podwójna, bo z jednej strony tradycyjna, wynikająca z nauk kościelnych, z drugiej zaś komunistyczna, bo tak zwana moralność socjalistyczna [...] była w tych materiach nader rygorystyczna" (cyt. za: Tomasik 2012: 19). Co interesujące, przywołany powyżej fragment zdaje się częściowo przeczyć opinii Głowińskiego rozmówca sugeruje, że pomimo niewidzialności homoseksualności, w tamtym czasie "był z kolei jakiś większy chyba nacisk na humanizm". Ów humanizm oznacza według niego tolerancję dla inności, która, choć istotnie pozostawała niewypowiedziana, nie była przedmiotem wrogości, "szykanowania” czy "wytykania palcami”. Rozbieżność opinii wskazuje m.in. na istotne ograniczenie omawianego tu materiału badawczego, ukazującego (w przeważającej większości) głosy mężczyzn, których wspomnienia o homoseksualnym życiu w PRL składają się na "narracje o sukcesie". To relacje osób, które - szczególnie z perspektywy lat - nie postrzegają tego okresu jako w jakimkolwiek stopniu 
ograniczającego ich samorealizację, identyfikację, możliwość wchodzenia w związki (erotyczne, romantyczne) z osobami tej samej płci. Przeciwnie, wielu rozmówców podkreśla, że aura "tajemnicy” czy "niewypowiedzenia”, jaka towarzyszyła homoseksualności, bardzo im odpowiadała, i wcale nie poczuwali się do bycia kimś gorszym czy wyalienowanym od reszty społeczeństwa.

Niektórzy rozmówcy poszukiwali informacji na własną rękę, sięgając m.in. po publikacje pisane przez seksuologów, w których pojawiały się wzmianki o homoseksualizmie:

Jak byłem licealistą, no to normalnie poszedłem do księgarni i kupiłem książkę profesora Jaczewskiego „Co każdy chłopak wiedzieć powinien”, czy coś w tym stylu. Więc ja nie miałem problemu, żeby wejść do księgarni. [...] Ja już nie pamiętam, ale jakoś na mnie to nie zrobiło wielkiego wrażenia. Była to po prostu jakaś taka skarbnica wiedzy, i myślę, że to nie było stygmatyzujące czy złe. Nie... (mężczyzna, 60 lat, Warszawa, wykształcenie średnie).

No wiesz, o tak zwanym gejostwie, czyli pedalstwie, w PRL-u się mówiło. Czy to w kręgach szkolnych, prawda, rówieśniczych. Więc wiedziałem, że jest taka kategoria mężczyzn, których pociągają inni mężczyźni. [...] Ta strona wulgarna miała jakby swój wymiar oczywisty tutaj. Natomiast pamiętam, kiedyś w ramach takiego grzebania, szukania różnych tajemnych zakamarków, dobrałem się do książki, którą znalazłem gdzieś ukrytą w szafie u rodziców. To był podręcznik seksuologii doktora Kazimierza Imielińskiego. [...] No i przeczytałem rozdział oczywiście także i ten. [śmiech] Starając się, wiesz, to jakoś sobie ustawić (mężczyzna, 61 lat, Warszawa, wykształcenie wyższe).

W przypadku obu rozmówców dążenie do zrozumienia seksualnych preferencji zostało częściowo zaspokojone lekturą podręczników seksuologii, będących "skarbnicą wiedzy" o zjawisku, które poza tym funkcjonowało wyłącznie jako obelga znana ze szkoły czy podwórka. Pierwszy rozmówca wspomina o Andrzeju Jaczewskim, który był współautorem (wraz z Jerzym Żmijewskim) Książki dla chłopców (1973), z kolei tytuł Co chce wiedzieć każdy chłopiec nosiła w rzeczywistości książka Janusza Łopuskiego (1957). Pomieszanie ze sobą autora i tytułu publikacji utrudnia stwierdzenie, do której z książek dotarł rozmówca, chociaż w podręczniku Jaczewskiego i Żmijewskiego - wcześniej opublikowanym pod tytułem Między nami mężczyznami (1964) - rozdział dotyczący homoseksualizmu zawiera treści o charakterze homofobicznym, co zdaje się przeczyć wspomnieniu rozmówcy o tym, „że nie było to stygmatyzujące". W przypadku drugiego rozmówcy chodzi zapewne o książkę Zaburzenia psychoseksualne (1970) Kazimierza Imielińskiego, w którym została m.in. omówiona tzw. skala Kinseya (zob. Kościańska 2017: 217-239). We wspomnieniach rozmówcy staje się ona bezcennym znaleziskiem pruderyjnie ukrytym przez rodziców "gdzieś w szafie" (co jest samo w sobie interesującą grą słowną z "byciem w szafie”), którego lektura pozwala mu "sobie ustawić" własne doświadczenie homoseksualności. Poszukiwanie informacji o homoseksualności stanowiło ważny 
krok w procesie tożsamościowym wielu rozmówców - dawało pewność tego, że nie jest się odosobnionym:

Kojarzę Imielińskiego i jego książki. Bardziej nawet Jaczewskiego. Z tym, że nie miałem ich w swojej biblioteczce. Na pewno je czytałem. Słuchaj, ja naprawdę do tego podchodziłem jakoś bardzo normalnie. Chciałem się dowiedzieć, wychodząc z założenia, że skoro ja już jestem taki, no to warto mieć jakąś głębszą wiedzę na ten temat (mężczyzna, 61 lat, Warszawa, wykształcenie wyższe).

\section{„Dawała mi wyraźnie do zrozumienia, że w pełni jak gdyby akceptuje tę naszą relację". Relacje $z$ rodziną}

Kwestia samookreślenia siebie w stosunku do większości rówieśników - nazwania tego, co pozostawało przemilczane w publicznym dyskursie Polski Ludowej - warunkowała również relacje z najbliższym otoczeniem: rodzicami i rodzeństwem. Większość moich rozmówców przyznawała, że nigdy nie rozmawiali otwarcie ze swoimi rodzicami o swojej orientacji seksualnej ani w młodości, ani w życiu dorosłym. Na pytanie o powody takiej decyzji, odpowiedzi padały różne. Niektórzy stanowczo oddzielali swoje życie prywatne od życia rodzinnego, tłumacząc, że nigdy nie czuli potrzeby dokonywania coming outu. Z niektórych relacji można wysnuć wniosek, że temat homoseksualności był na tyle wstydliwy - pomimo tego, że sami rozmówcy nie mieli problemu z akceptacją swojej orientacji - bo dotyczący sfery seksualności i praktyk seksualnych, że trudno było o tym rozmawiać z rodzicami. Brakowało języka do wyrażenia tego, czym jest "odmienność" syna.

Przemilczanie tematu homoseksualności nie zawsze oznaczało jednak, że moi rozmówcy nie czuli się akceptowani wśród najbliższych członków rodziny:

[...] jak miałem 24 lata, byłem na trzecim roku studiów, spotkałem faceta, z którym spędziłem jedenaście lat $w$ jednym mieszkaniu. On poznał moją rodzinę, moja rodzina poznała jego, odwiedzali się nawzajem. Więc jakoś to było takie spokojne i naturalne. A jednocześnie pamiętam, że ja nigdy w swoim domu, z mamą czy z rodzeństwem, myśmy nigdy na ten temat nie rozmawiali, nie. Natomiast oni wszyscy znali tych facetów, wiedzieli kto jest kto (mężczyzna, 60 lat, Warszawa, wykształcenie wyższe).

To znaczy z rodzicami jako takimi ja na ten temat właściwie nie rozmawiałem. Ojciec umarł wcześniej trochę, a matka, ona jak tam jakieś ciotki jej się, „a kiedy tam się ożenisz?", coś takiego, "dajcie mu spokój” - wiesz, tego typu było podejście (mężczyzna, 63 lata, Warszawa, wykształcenie wyższe). 
Wspólnym doświadczeniem prawie wszystkich moich rozmówców było właśnie przemilczanie tematu homoseksualności, „tego typu podejście” zakładające, że pozostaje to rozpoznane przez rodziców jedynie w domyśle, bez nazywania rzeczy otwarcie. Rodzina wiedziała o (albo przynajmniej domyślała się) ich orientacji i związkach z mężczyznami, ale nigdy nie stawało się to przedmiotem rozmowy. Chociaż zazwyczaj rozmówcy deklarowali, że był to rezultat ich decyzji, czasem przywoływali anegdotyczne opowieści o tym, jak członkowie najbliższej rodziny podejmowali próby "sondowania":

Pamiętam sytuację taką, że pojechaliśmy do moich rodziców, i siedzieliśmy wieczorem tam przy stole. No i tam matka z ojcem: "no a czemu to, a tego"... I w pewnym momencie, już nie pamiętam, chyba matka powiedziała: „A może ty wolisz chłopców?" Więc ja powiedziałem, że: „No, może”. I w związku z tym, że na głupie pytanie jest głupia odpowiedź, to już przestano na ten temat rozmawiać [śmiech] (mężczyzna, 73 lata, Poznań, wykształcenie wyższe).

W przywołanej relacji potencjalnie nieprzyjemna sytuacja wyautowania zostaje rozbrojona dowcipem, ujawniającym również stosunek rozmówcy do samej idei coming outu: „na głupie pytanie jest głupia odpowiedź". Pomimo interpelacji ze strony matki - swoistego "wezwania” do ujawnienia swojej orientacji - mężczyzna nie decyduje się na coming out. Uchylanie się od udzielenia jednoznacznej odpowiedzi matce przywołane jest, znów, bez użycia kategorii tożsamościowych („homoseksualista", "gej") - we wspomnieniach matka pyta jedynie, czy podobają mu się mężczyźni. Z drugiej strony, przywołana odpowiedź („no, może”), chociaż pozostaje w sferze niedopowiedzenia, może być również odczytana dwuznacznie, jako przyznanie się, że być może „woli chłopców”. Narracje rozmówców o tym, jak kształtowały się ich relacje z rodziną charakteryzuje nacisk na dyskrecję, przemilczanie tematu albo pozostawienie go w sferze domysłów. Zamiast o coming oucie, mówią o „otwarciu się", którego nie potrzebowali. W rzadkich przypadkach rozmówcy starali się jednak przełamać obopólnie podtrzymywaną z rodzicami zmowę milczenia, próbując wyrazić słowami to, co czuli, nawet pomimo strachu przed napiętnowaniem:

Przed ojcem to ukrywałem, bo się bałem. Mamie powiedziałem. „Coś muszę mamie powiedzieć". Uklęknąłem przed nią, jak przed matką. I jej powiedziałem, że czuję się troszkę inny, a wcale nie gorszy. Powiedziała: „Rób jak uważasz, uważaj co robisz". To były chyba najmądrzejsze słowa matki. Tak do dzisiaj jest (mężczyzna, 59 lat, Poznań, wykształcenie średnie).

Na podstawie przedstawionych relacji można stwierdzić, że homoseksualność w PRL funkcjonowała jako "sprawa prywatna" i „otwarty sekret”, nawet u tych mężczyzn, którzy czuli się akceptowani pomimo swojej nienormatywnej seksualności. Co istotne, wielu moich rozmówców nie postrzegało tego stanu rzeczy jako obciążenia, nie mieli ani wyrzutów sumienia, ani pretensji; przeciwnie, zazwyczaj podkreślali to, że najważniejsza była dla nich akceptacja ze strony rodziny, nawet jeśli komunikowana była na zasadzie "cichej zgody", bez nazwania wprost ani ich orientacji czy tożsamości, ani natury 
związków z mężczyznami. Często powracającym wątkiem w narracjach są historie związane z odwiedzinami w domu rodzinnym (np. z okazji świąt, uroczystości rodzinnych, albo po prostu z wizytą) z „przyjaciółmi” - wieloletnimi partnerami:

A zwłaszcza kiedy ta relacja ze Stanisławem trwała, no to ona [matka - przyp. JB] zaczęła Stanisława traktować jako swojego drugiego syna. Dawała mi wyraźnie do zrozumienia, że w pełni jak gdyby akceptuje tę naszą relację (mężczyzna, 61 lat, Warszawa, wykształcenie wyższe).

Jak ja tam przyjechałem do nich, to jego mama i jego ojciec mówili: przyjechał nasz drugi syn. Bo on był jedynakiem, miał dwie siostry. [...] Znajomi ich akceptowali nas. Nie mówiło się nigdy, że jesteśmy gejami czy coś tego. To było zupełnie naturalne. Przyjechał Artur z Tomkiem. Na święta, na wakacje (mężczyzna, 73 lat, Poznań, wykształcenie wyższe).

Określanie przez rodziców partnera rozmówcy jako "drugiego syna" pojawia się w wielu narracjach. Sami rozmówcy raczej wzdragają się przed określaniem swoich wieloletnich związków romantycznych - nawet z partnerami, z którymi tworzyli wspólne gospodarstwa domowe - przy użyciu heteronormatywnego języka: nie mówią nigdy o "mężach", rzadko nazywają ich "chłopakami” czy nawet „partnerami”, a właśnie - „przyjaciółmi”, czasem „kochankami”. Słowo „przyjaciel” określa zresztą różne układy partnerskie i romantyczne, niekoniecznie sprowadzające się do modelu monogamicznego. Zarazem jednak owi "przyjaciele” traktowani byli przez rodziny jako faktyczni partnerzy synów, "drudzy synowie", funkcjonujący wedle tych samych zasad, co np. małżonkowie ich rodzeństwa:

W każdym razie był oddzielny pokój, w którym żeśmy spali. I przyjeżdżaliśmy, to było wiadomo, że będziemy tam spać. I zawsze było, siostra się pyta: „Pościelić wam tam"? Tak, tak, tak. No, to było zupełnie naturalne (mężczyzna, 73 lat, Poznań, wykształcenie wyższe).

Jak kiedyś tam, pamiętam, z takim pierwszym moim chłopakiem, że pojedziemy [...] z wizytą, no tam, że przyjadę z kolegą, coś tam, no to mama nam pościeliła jedno łóżko mimo że były dwa, wiesz. Także z tego punktu mogę powiedzieć, że byłem w bardzo szczęśliwej sytuacji na tle wielu, poza tym miałem kolegów, którzy mieli nieustanne wojny z rodziną (mężczyzna, 63 lata, Warszawa, wykształcenie wyższe). Nie, wręcz odwrotnie, wręcz odwrotnie, miałem wielkie poparcie w postaci swojego ojca, który, jak przyprowadziłem do domu, odważyłem się przyprowadzić jednego z moich bliskich wtedy już mogę nazwać, uznać i określić go mianem kochanka, to mój ojciec w czasie świąt posadził, a był również moim imiennikiem, posadziłjego 
na jednym kolanie, mnie na drugim, obydwu nas objął przy całej rodzinie, mówi: "Cieszę się, że mam dwóch synów" (mężczyzna, 80 lat, Warszawa, wykształcenie średnie).

Ciekawym przykładem narracji ukazującej kłopot z rozmową na temat homoseksualności ukazuje poniższy fragment, w którym rozmówca opowiada o reakcji swojej matki na głośny artykuł Barbary Pietkiewicz pt. „Gorzki fiolet” z 1981 roku, jeden z pierwszych tekstów otwarcie i empatycznie poruszający temat homoseksualizmu:

Natomiast pojawiały się i wcześniej w prasie artykuły, które robiły na mnie wrażenie. Zresztą na mojej matce również. Ja zwróciłem uwagę na artykuł Darka Proroka z 1985 roku, ale przecież w siedemdziesiątym którymś pisała na ten temat Barbara Pietkiewicz w "Polityce”, w też głośnym tekście. I pewna scena była... powiedziałbym emblematyczna. Robiąca na mnie i na mojej matce wrażenie, no, w zasadzie takie same, z całkiem różnych powodów. Moja matka przeczytała o profesorze tokującym przy szalecie przy placu Trzech Krzyży, profesorze uniwersytetu jakby. No i był to obraz takiego krańcowego upodlenia starego, zabiegającego o chwilę radości homoseksualisty. I jako że ja byłem jej oczkiem w głowie, ona sobie od razu wyobraziła, że mnie czeka taki sam los. I nalegała, żeby to się nie stało. [...] Natomiast o takich rzeczach się nie mówiło. Także ten artykuł, jak mówię, był nieprzedyskutowany, nieprzemyślany. A jeżeli przemyślany, to ja i moja matka myśleliśmy o nim osobno. To wyszło dopiero po latach, kiedy już byłem na studiach, kiedy moja matka nawiązując właśnie do tego, że nie widzi mnie w towarzystwie dziewczyn. „Ja nie chcę żebyś był taki, ja nie chcę żebyś był taki jak ten profesor" (mężczyzna, 61 lat, Warszawa, wykształcenie wyższe).

Mimo tego, że rozmówca wskazuje mylną datę ukazania się artykułu Pietkiewicz w „Polityce", w jego wspomnieniach na pierwszy plan wysuwa się reakcja matki - strach przed tym, żeby jej syn nie podzielił losu "starego, zabiegającego o chwilę radości homoseksualisty". Pokazuje to znaczenie, jakie miały wczesne publikacje prasowe - Proroka, Pietkiewicz, Szczygła - dla możliwości rozmowy na temat homoseksualności dziecka, nawet jeśli, jak w tym przypadku, rozmówca musiał w rezultacie zmierzyć się ze stereotypem nieszczęśliwego homoseksualisty z pikiety. Istotne jest wskazanie, że temat ten "był nieprzedyskutowany, nieprzemyślany” - znacząca nieobecność homoseksualności w dyskursie publicznym PRL została przełamana dopiero w latach późniejszych.

Wspomnienia o relacjach z rodziną ujawniają charakterystyczną cechę pokolenia homoseksualnych mężczyzn dorastających w tym okresie PRL: odrzucenie idei "coming outu" wobec najbliższego środowiska rodzinnego jako niezbędnego elementu w procesie kształtowania tożsamości homoseksualnej. Przedstawiając wyniki swoich badań jakościowych nad współczesnym rozumieniem praktyki 
coming outu wśród polskich gejów, Marcin Welenc zwraca uwagę, że grupa starszych badanych (w przedziale 35-45 lat) nie dokonała nigdy coming outu rodzinnego: „Ich seksualna tożsamość pozostaje raczej w sferze niedomówienia (»tajemnica poliszynela«) i jest niekiedy znana rodzeństwu, częściej - przyjaciołom, którzy »wiedzą [...] grupa starszych badanych ceni tożsamościową nieokreśloność, niekonieczność określania siebie, wielość i płynność. Nauczyli się żyć w tego typu relacji i korzystać z oferowanych przez nie możliwości" (Welenc 2018: 176-194). Podobne wnioski można wysnuć z narracji moich rozmówców, starszych o kilkanaście-kilkadziesiąt lat od grupy badanej przez Welenca. O ile jednak "sfera niedomówienia” rozciągająca się na rodziców (rzadziej na rodzeństwo, z którym inaczej układa się relacje) pozwala również oddzielać od siebie dwa prywatne światy - świat rodzinny i świat osobisty - o tyle wspólnym doświadczeniem moich rozmówców jest innego rodzaju coming out: „otwarcie się" na społeczność, poczucie przynależności do różnych miejskich wspólnot homoseksualnych mężczyzn funkcjonujących w PRL.

\section{„I później jakieś tam różne niesnaski, a bo ten chciał z tym, a ta nie chciała, no jak to w środowisku". Różowy język społeczności homoseksualnych w PRL}

Rozmówców łączy fakt, że wszyscy, niezależnie od miejsca urodzenia i dorastania, spędzili lata 70. i 80. w dużych polskich miastach: w Warszawie, Poznaniu, Wrocławiu lub Toruniu. Jak podsumował to jeden z nich, dopiero od przeprowadzki do stolicy „zaczęło się, że tak powiem, gejostwo na szeroką skalę". Niezależnie od różnych trajektorii życiowych, indywidualnych wyborów czy karier zawodowych, duże ośrodki oferowały znacznie więcej możliwości kontaktów z innymi homoseksualnymi mężczyznami. O istotnym znaczeniu przestrzeni miasta dla konstytuowania się tożsamości homoseksualnej pisze Bartek Lis: "Seksualność zostaje uwolniona przez występowanie w anonimowej, zatłoczonej przestrzeni miejskiej. W tych okolicznościach zyskuje nowe możliwości realizacji, a tym samym z przygodnego, epizodycznego doświadczenia zamienia się w praktykę osadzoną w konkretnym kontekście. Staje się procesem, ciągłą i w miarę spójną opowieścią zanurzoną w siatce ulic, miejskich parków i skwerów" (Lis 2009: 105). Pocztą pantoflową roznosiło się informacje o lokalizacjach pikiet - określonych miejsc w przestrzeni publicznej służących do kruzingu (cruising), w których homoseksualni mężczyźni spotykali się na seks (zazwyczaj anonimowy, chociaż pikiety służyły też do poznawania osób, z którymi wchodziło się w dłuższe związki). Pikiety funkcjonowały zazwyczaj w wybranych parkach (np. Park Skaryszewski w Warszawie, Park Cytadela w Poznaniu) oraz szaletach i toaletach publicznych: na dworcach kolejowych i uczelniach, albo w wolnostojących "blaszakach" z pisuarami, jak najsławniejszy w Warszawie "grzybek" na Placu Trzech Krzyży. Podobny cel spełniały publiczne łaźnie i sauny, choć były to miejsca stosunkowo mniej anonimowe - a być może wręcz wspólnoto-twórcze - jako że często odwiedzali je regularnie ci sami mężczyźni, którym relatywna swoboda panująca $w$ tych homospołecznych przestrzeniach pozwalała również na prowadzenie nieskrępowanych rozmów, na dzielenie się plotkami, poradami czy wspomnieniami, a tym samym przyczyniała się do wzmacniania poczucia przynależności do określonej społeczności. W opowieściach rozmówców świat pikiet nieodłącznie wiązany jest z realiami codziennego życia homoseksualnych mężczyzn w PRL. Niewielu wyraża tęsknotę za tymi miejscami, traktując je raczej jako nieod- 
łączną część składową ówczesnego życia gejowskiego, z dzisiejszej perspektywy postrzeganą jako wstydliwe i „brudne” (z różnych powodów) wspomnienie ograniczonego pola do ekspresji nienormatywnej seksualności. Jak to ujął jeden z moich rozmówców, "na pikietę nigdy nie chodziło się trzeźwym". Co istotne, dla tych, którzy przeprowadzili się do dużego miasta ze wsi albo mniejszego miasteczka, pikiety stanowiły odkrycie. Pikieta była subwersywną lokalizacją niejako „wyrwaną” z heteroseksualnie naznaczonej czy też "poskromionej” miejskiej przestrzeni publicznej, "seksualnym laboratorium" (Lis 2009), w którym po raz pierwszy uświadamiali sobie powszechność homoseksualności:

No i pewnego razu wszedłem się wysikać, i nagle widzę po prawej, po lewej stronie, bo to były okrąglaczki, stoją starsi panowie, którzy wymachują fiutkami, no kurcze, co się dzieje? No, ale wysikałem się i uciekłem stamtąd, i tyle było z tego pierwszego razu (mężczyzna, 60 lat, Warszawa, wykształcenie wyższe).

W większych miastach zazwyczaj funkcjonowały kawiarnie albo bary, które określało się czasem jako „ukierunkowane” - dziś moglibyśmy uznać je za miejsca gay-friendly - o których wiadomo było, że odwiedzają je przede wszystkim osoby homoseksualne ${ }^{4}$.

Zresztą to bardzo, taka dziwna, ale charakterystyczna sprawa, że będąc w Warszawie, już po studiach, nigdy się nie odważyłem, chociaż przechodziłem bardzo często, nie odważyłem się wejść do słynnej Amatorskiej, na Nowym Świecie. Do tego stopnia to była jakaś taka presja, bo wiadomo było wtedy, że jak się już tam weszło, to się miało etykietkę, prawda? (mężczyzna, 72 lata, Paryż, wykształcenie wyższe).

Do Ambasadora, tam naprzeciwko Ambasady Amerykańskiej, to była wielka restauracja, restauracja prawie nigdy w ogóle nie była zajęta, natomiast barek był okupowany, to całe grona tych gejów, tam też, to wiadomo tam też królowały te wszystkie największe te takie postacie gejowskiego, to później jak się... Jak oczywiście w operze... Chodziły te kulturalne cioty do opery, to oczywiście nawet jak ja byłem z żoną, to ona też to musiała widzieć, że, że spojrzenia nasze zawsze się spotykały [śmiech]. Tak. To, czyli w mieszkaniach, wszystko było w mieszkaniach, nie było klubów, nie było (mężczyzna, 71 lat, Warszawa, wykształcenie wyższe).

\footnotetext{
${ }^{4}$ Kwestia identyfikacji „lokali homoseksualnych" nie zawsze była jednak tak oczywista dla wszystkich rozmówców, o czym świadczy poniższa relacja: „O Amatorskiej to [...] nie wiem, ponieważ dowiedziałem się o tym właściwie znacznie, znacznie później, już nieomal z historii. I mnie to zdziwiło, ponieważ rzeczywiście do Amatorskiej na studiach bardzo często zachodziłem, bo to na szlaku na Nowym Świecie, i prawie co drugi-trzeci dzień zachodziłem tam na kawkę. Po prostu na kawę, i nigdy jakoś niczego nie zauważyłem, no może dlatego że nie szukałem, ale i nie widziałem. Co do Amatorskiej to ja nie wiem, to mi się wydaje trochę legendą" (mężczyzna, 70 lat, Warszawa, wykształcenie wyższe).
} 
O barwnym świecie warszawskich lokali pisze w swojej głośnej książce Foucault w Warszawie Remigiusz Ryziński (2017), skupiając się na okresie późnych lat 50. i wczesnych 60., chociaż spora część opisywanych lokali prosperowała również w latach późniejszych (a nieliczne - do dzisiaj). Równolegle do większej widoczności homoseksualności w przestrzeni miejskiej Warszawy czy Poznania, w dużych ośrodkach funkcjonowały zazwyczaj różne nieformalne grupy towarzyskie tworzone przez osoby homoseksualne. Chociaż zgadzam się z propozycją Jerzego Krzyszpienia, że w odniesieniu do wspólnot gejów i lesbijek właściwym określeniem jest słowo "społeczność" - podkreślające to, że jego członków łączą bliskie relacje (Krzyszpień 2010: 144) - badani zazwyczaj mówią o "środowisku" czy też "branży” (chociaż to drugie określenie weszło do powszechnego użycia dopiero na przełomie lat 80. i 90.). Były to społeczności do pewnego stopnia ekskluzywne, we wspomnieniach moich rozmówców wiązane z albo z gronem najbliższych przyjaciół (lub bardziej wąsko), albo z lokalnymi kręgami elit społeczno-kulturalnych (szerzej), które bywały najbardziej „nasycone tą orientacją".

W odniesieniu do okresu PRL nie można oczywiście mówić o istnieniu jednej społeczności gejowskiej, ale o różnych, mniejszych lub większych, grupach przyjacielskich i towarzyskich, częstokroć wykraczających poza dane miasto. Co więcej, w dużych miastach funkcjonowały również "salony gejowskie", prowadzone zazwyczaj przez zamożniejszych, starszych mężczyzn z kręgów artystycznointelektualnych. Niektóre przyjmowały charakter prawie że instytucjonalny, stając się nieformalnymi „centrami” homoseksualnych społeczności PRL-u, wzmacniając nie tylko poczucie wspólnoty, ale i przyczyniając się do kształtowania się "kultury gejowskiej” - począwszy od języka (slangu, żargonu), przez praktyki kulturowe (m.in. występy dragowe, bale przebierane), a skończywszy na tworzeniu kanonu tekstów kultury. Na salonach śledzono zarówno literaturę polską, wyczytując homoerotyczne „momenty” pojawiające się m.in. u Jerzego Andrzejewskiego czy Jarosława Iwaszkiewicza, jak i pojawiające się pierwsze tłumaczenie m.in. gejowskiej prozy afroamerykańskiego pisarza Jamesa Baldwina. Samo określenie "salon" wydaje się interesujące; z jednej strony ma wartość nobilitującą, kojarząc się z kulturą arystokratyczną czy mieszczańską, z drugiej zaś może być też odczytywane w kontekście zorientowania na Zachód. W odniesieniu do peerelowskiego życia nienormatywnego można mówić o specyficznej odsłonie „cywilizacji mieszkania”, typowej dla polskich lat 70., wynikającej z ograniczonego dostępu do mieszkań (szczególnie dla osób młodych czy samotnych). Jak ujął to jeden z rozmówców, "życie gejowskie toczyło się w mieszkaniach prywatnych”. To tam urządzało się prywatki czy przyjęcia, na których spotykali się zarówno wieloletni znajomi i bliscy przyjaciele (w tym nierzadko śmietanka ówczesnych elit kulturalnych - aktorzy, piosenkarze), jak i nowo poznani - w teatrze czy operze, w kawiarni czy na pikiecie - homoseksualni mężczyźni, częstokroć "wprowadzani" do towarzystwa przez zaufane osoby.

Peerelowskie społeczności homoseksualne charakteryzował oczywiście osobny „żargon”, który Tomasz Łukasz Nowak - dokonując analizy językowej zarówno pierwszych polskich pism gejowskich z lat 90., jak i Lubiewa Witkowskiego - określa jako socjolekt gejowski ("ciotowski”, „pedalski”), zwracając jednak uwagę, że ten socjolekt był negocjowany dopiero w okresie potransformacyjnym, 
wraz z pojawieniem się na rynku pism takich jak "Inaczej”, "Nowy Men” czy "Okay” (Nowak 2016). W przypadku narracji traktujących o późnych latach PRL, przy próbie rekonstrukcji specyfiki językowej różnych "środowisk”, w których funkcjonowali moi rozmówcy, o wiele trudniej ustalić, co właściwie zalicza się do "slangu gejowskiego" - i czy w ogóle w odniesieniu do tamtego okresu można mówić o istnieniu jednego wspólnego „różowego języka?” Naturalnie, pewne wyrażenia czy praktyki językowe wydają się stosunkowo powszechne - począwszy od tego, jak mówili o sobie nawzajem (a czasem też zwracali się do siebie) homoseksualni mężczyźni:

No nie było czegoś takiego [jak gej - przyp. JB], więc no po prostu były "pedały" i to wszystko. Albo były "koleżanki", o. No tak między sobą, no to się raczej mówiło per koleżanki. Natomiast wszyscy uważali, i spluwali, mówiąc "pedał” (mężczyzna, 60 lat, Warszawa, wykształcenie wyższe).

Mówiło się, "nasza”, „idzie nasza”. Albo... Znaczy to były różne określenia, bo o... albo "o, idzie misiaczek" na przykład... (mężczyzna, 72 lata, Warszawa, wykształcenie średnie).

Ale tak to raczej, no to często się mówiło, że "ona", używało formy żeńskiej. No "koleżanki" się mówiło, że to „koleżanka”. Ciotka, koleżanka, przyjaciółka, siostra. W tym sensie, żeńskie. No i przezwiska też oczywiście były żeńskie, pseudonimy (mężczyzna, 70 lat, Poznań, wykształcenie wyższe).

Przytoczone przykłady ujawniają dwie cechy środowiskowego żargonu. Po pierwsze, w odniesieniu do osób „zorientowanych" używało się żeńskich form, z których najpowszechniejszą była "koleżanka”, choć używano również innych, takich jak "ciotka”, "siostra”, „przyjaciółka”. Co szczególnie zastanawiające w świetle dotychczasowych badań nad homoseksualnością w PRL, homoseksualni mężczyźni, z którymi rozmawiałem niekoniecznie utożsamiają się z kategorią „cioty” w takim stopniu, jak zdaje się sugerować to dyskurs uznający „subkulturę ciot” za nienormatywną społeczność reprezentatywną dla Polski Ludowej ${ }^{5}$. Drugą kwestią jest stosunek rozmówców do określenia "pedał”. Dla wielu z nich ta kategoria tożsamościowa pozostaje problematyczna, na co wskazuje pierwszy rozmówca, podkreślając, że „wszyscy uważali, i spluwali, mówiąc "pedał«". Niektórzy nie utożsamiają się z tym określeniem do dzisiaj, tłumacząc to jego pejoratywnym zabarwieniem i związkiem z określeniem „pederasta", dziś jednoznacznie homofobicznym, w PRL funkcjonującym jednak dość powszechnie w dyskursie publicznym (a przez to być może mającym bardziej neutralny wydźwięk niż „pedał”).

${ }^{5}$ Być może niechęć części moich rozmówców do identyfikowania się z etykietką „cioty” ma związek z opisywanym przez Ludmiłę Janion pejoratywnym polem semantycznym tego słowa (odniesienie do menstruacji, nieczystości), a co za tym idzie z „mizoginicznymi konotacjami kobiecości jako czegoś nieczystego, wadliwej seksualności i niekontrolowanej fizjologii" (Janion 2018: 37). 
Jednocześnie wielu rozmówców pozostaje sceptyczna wobec określenia "gej": „Pederaści, pederaści byli, tak. Ale nigdy mnie słowo "pedał” nie obrażało. Wiedziałem, że nie ma innego. Natomiast słowo "gej" mi się nie podoba i właściwie ja tego nie używam" (mężczyzna, 60 lat, Warszawa, wykształcenie wyższe).

Chociaż moi rozmówcy czasem używają słowa "gej" do opisu rzeczywistości peerelowskiej - mówiąc np. o gejowskich kawiarniach, prywatkach, miejscach spotkań - jednocześnie zwracają uwagę na anachroniczność tego słowa, które w polskim dyskursie publicznym zaczęło funkcjonować dopiero od drugiej połowy lat 80. (zob. np. Basiuk w tym numerze).

Co więcej - i co jest akurat zgodne zarówno z wcześniejszymi ustaleniami badaczy, jak i z konwencją przyjętą w Lubiewie Witkowskiego - wielu homoseksualnych mężczyzn w swoich grupach towarzyskich "występowało" pod pseudonimem. Prawie zawsze było to imię żeńskie (chociaż czasem zaczerpnięte z języka angielskiego bądź francuskiego), albo imiona fikcyjnych postaci zapożyczone z literatury, teatru, kina czy tekstów popularnych piosenek. W tym fragmencie rozmówca szczegółowo omawia genezę kilku pseudonimów funkcjonujących wśród jego przyjaciół:

[...] w tej rewii, któraś z aktorek Teatru Syrena, nie pamiętam, może to była Stefcia Górska, może to była Lidia Wysocka, to nie ma znaczenia, ale śpiewały piosenkę Zuli Pogorzelskiej. [...] tam się śpiewało, znaczy w tekście było, „to Zula, to Zula w futerko się otula" ${ }^{6}$. I myśmy wyszli z teatru i w holu Teatru Syrena, idąc po drodze do szatni tenże Zbyszek, pseudonim Maryla, tak jakoś wybuchnął, pełen energii, jakoś mówi: „Słuchajcie, to musimy zacząć, przerabiamy tę piosenkę, i będziemy śpiewali "to Lulla, to Lulla w futerko się otula", i tak przykleili do mnie ten pseudonim. [...] Bo jeszcze wcześniej jedna z moich koleżanek, też adwokat [...], ona jeszcze wcześniej wymyśliła o mnie pseudonim, to "Luna”, kobieta księżycowa, od, że księżyc tu, i tak to się... ale potem wszyscy uznali, że to Lulla, to Lulla to jest fajniejsze bardziej, brzmiące ciekawiej i tak zostało do dzisiaj. Natomiast był taki na przykład pseudonim Rita Szczoteczka. [...] to był kustosz, który jak szedł na tak zwaną randkę, bo nigdy nie wiedział, czy wróci do domu, to zawsze w butonierce miał szczoteczkę do zębów. Bo myślał, że go zastanie poranek i będzie musiał iść do muzeum, więc chciał mieć zawsze umyte zęby. Był taki pseudonim, który nosił tenże już nieżyjący stomatolog... Nosił, nosił pseudo Noemi. I skąd się to wzięło? Wzięło to się z piosenki, którą śpiewała Ludmiła Jakubczak i tam w piosence był

${ }^{6}$ Chodzi o piosenkę "To Zula" z 1927 roku, kompozycję Szymona Kataszka do tekstu autorstwa Andrzeja Własta, poświęconą postaci Zofii Pogorzelskiej (1898-1936), międzywojennej tancerki, aktorki i piosenkarki kabaretów i teatrów rewiowych. 
taki tekst "Noemi to prawdziwa dama, Noemi biodra ma jak hamak", bo Andrzej miał takie bardzo szerokie biodra i się kołysał ${ }^{7}$ (mężczyzna, 80 lat, Warszawa, wykształcenie średnie).

Zarówno korzystanie z żeńskich pseudonimów, jak i powszechne określanie się jako "koleżanki", wskazuje na subwersywne queerowanie ówczesnego rozumienia procesów tożsamościowych, w tym - kwestionowanie kategorii płciowych i potocznych wyobrażeń o "męskości” czy "niemęskości”:

Słynne było jego wystąpienie jako Liza Minnelli z "Kabaretu”. On miał taką fajną figurkę, drobniutki chłopaczek, ale w sam raz, tak jak Liza Minnelli. Jak się ubrał w odpowiedni strój, perukę, no to wiadomo, nie? I śpiewał. Także to były słynne. I takie sylwestry tam się odbywały, to była elita. No oczywiście plotek cała masa. [śmiech] I później jakieś tam różne niesnaski, a bo ten chciał z tym, a ta nie chciała, no jak to w środowisku. Tak to się wszystko odbywało (mężczyzna, 70 lat, Poznań, wykształcenie wyższe).

Rozmówca wspomina imprezę sylwestrową odbywającą się w jednym z poznańskich "salonów gejowskich", przywołując historię dragowego występu jednego z uczestników, przebranego za Lizę Minnelli z filmu Kabaret (USA 1972). Wskazuje to nie tylko na cyrkulację artefaktów i tekstów zachodniej kultury gejowskiej już w późnych latach 70. - wbrew dominującej wciąż narracji o izolacji bloku komunistycznego, podważanej m.in. przez Łukasza Szulca (2018) - ale i na otwartość na występy przełamujące czy „przeginające” kategorie płciowe. Z perspektywy językowej interesująca jest zwłaszcza druga część wypowiedzi, w której rozmówca śmieje się z różnych towarzyskich afer wybuchających podczas tego typu spotkań: „a bo ten chciał z tym, a ta nie chciała, no jak to w środowisku". Płynne przechodzenie pomiędzy formami męską i żeńską obrazuje fundamentalną "queerowość" socjolektu gejowskiego, na którą zwraca uwagę Nowak: "Całość tworzy kampowa przestrzeń, kabaret, które stają się rzeczywistością ciotowskiej społeczności »jeżdżącej do Sopotu« i »biegającej na pikiety«" (Nowak 2016: 177).

Jeśli chodzi o samoidentyfikację, jak i odnoszenie się do innych mężczyzn ze społeczności, moi rozmówcy stosują się język aluzyjny, sugerujący czyjąś "odmieńczość", ale nie definiujący jej w kategoriach tożsamościowych: "chłopak zorientowany", "być zorientowanym (w orientacji)", "ten-teges”, "ciepły brat" ${ }^{\prime}$. Ktoś, kto pierwszy raz pojawiał się na pikiecie, był „pierwszym wydaniem”, a młody

${ }^{7}$ Chodzi o piosenkę „Alabama” z 1962 roku, wykonywaną przez piosenkarkę Ludmiłę Jakubczak.

8 Jeden z moich rozmówców sugerował, że określenie „ciepły brat" było używane głównie na wsi lub w mniejszych miejscowościach: „A w takich malutkich miejscowościach, typu jak ta Brodnica, to gdzieś tam ludzie wiedzieli, że tam ktoś tam z kimś tam. I to mówili na taką parkę »ciepli bracia«, »ciepły brat«, tak całkiem ciepło, jak to się mówi, nie tam jakieś pedały coś tam. Także »ciepły brat« to było pamiętam określenie na takich ludzi, takie dosyć powiedzmy, że neutralnosympatyczne nawet" (mężczyzna, 63 lata, Warszawa, wykształcenie wyższe). 
chłopak ("młode mięso") polecany innym był "obiektem” przekazywanym z rąk do rąk. Podobnie jak przyjmowane pseudonimy "sceniczne”, peerelowski "różowy język" charakteryzuje żartobliwość i figlarność, traktowanie się nie całkiem na poważnie. Mężczyzna rozbuchany seksualnie to „promiskuita”, wymiana partnerami seksualnymi określana jest jako "transfer", a miejski szlak pikiet wspominany jest jako "droga krzyżowa” czy "trakt kurewski” (w odniesieniu do Traktu Królewskiego w Warszawie). Często powtarzają się przywoływane anegdotyczne powiedzonka i przekomarzania, funkcjonujące w różnych kręgach towarzyskich:

Krążył taki dowcip: czym się różni rower od SGPIS-u? I odpowiedź: ilością pedałów. No bo tak było, tak było wtedy. [...] To były słynne, słynne toalety na tej uczelni (mężczyzna, 71 lat, Warszawa, wykształcenie wyższe).

Jak złodziej złodzieja, kurwa kurwę, tak pedał pedała pozna [śmiech] (mężczyzna, 61, Poznań, wykształcenie średnie).

Z żołnierzami przy grobie nieznanego żołnierza w Ogrodzie Saskim, że po nocach można było jak pogotowie ratunkowe ratować się, prawda, u nich [śmiech] (mężczyzna, 61 lat, Warszawa, wykształcenie wyższe).

Opowieści o przyjaźniach, prywatkach, przebieranych balach i codziennym życiu w dużych miastach w latach 70. pokazują proces tworzenia się wspólnoty - kształtowanie poczucia przynależności do szerszej „kultury gejowskiej”, wykraczającej zarówno poza indywidualny proces akceptacji homoseksualności, jak i poza anonimowe relacje zawierane w przestrzeniach pikiet. O ile orientacja czy tożsamość seksualna jest przez moich rozmówców postrzegana jako prywatna sprawa, a więc wiedza, którą nie trzeba było się dzielić z rodziną czy znajomymi z pracy, o tyle "otwarcie się" na społeczność homoseksualną stanowiło najważniejszy etap w procesie tożsamościowym. Ostrożność czy wręcz niechęć wobec dzisiejszej polityki LGBTQ pokazuje natomiast, jak odmienne było doświadczenie życia nienormatywnego w okresie przed emancypacją. Chociaż w PRL oficjalnie „nie istniał homoseksualizm", istniały różne społeczności gejowskie - przynajmniej w największych miastach - tworzone wokół subwersywnych przestrzeni, wybranych kawiarni, w prywatnych mieszkaniach bądź "salonach". Nienormatywnemu życiu homoseksualnych mężczyzn towarzyszyły niepisane reguły, praktyki kulturalne, rytuały, gust i moda, czy wreszcie - „różowy język", będący tyleż zbiorem słów i skojarzeń, co charakterystycznym stylem mówienia i myślenia o swojej „inności”. Był to język wypełniony żargonowymi określeniami, kodem rozpoznawalnym tylko dla wtajemniczonych i opartym na aluzji, sugestii, nienazywaniu niczego wprost.

Omówione w artykule narracje - naturalnie fragmentaryczne i reprezentatywne tylko dla określonej grupy mężczyzn - pokazują odmienne, przedemancypacyjne doświadczenie zarówno odkrywania i „układania sobie" tożsamości seksualnej, jak i stopniowe „otwieranie się" na szerszą społeczność (społeczności) homoseksualnych mężczyzn, a więc tę część historii polskiej homoseksualności, która 
nadal czeka na pogłębione i wielowątkowe opracowanie. Warto zwrócić uwagę na analogiczne procesy kształtowania się nowoczesnej tożsamości gejowskiej zachodzące zarówno w innych krajach byłego bloku socjalistycznego, np. w Czechach (Hall 2009), jak i poza Europą, np. w Republice Południowej Afryki (Donham 2012). Wskazane przykłady pokazują, że proces konstruowania tożsamości opartej na seksualności - identyfikowanie się jako gej czy lesbijka w ramach zachodnich kategorii tożsamościowych - oraz poczucia przynależności do wspólnoty wyobrażonej osób homoseksualnych niekoniecznie przyjmują taki kształt, jak zdaje się to sugerować dominujący dyskurs emancypacyjny ukształtowany przede wszystkim w Stanach Zjednoczonych. ${ }^{9}$ Istotny rozziew pomiędzy dyskursem tożsamościowym Zachodu a innymi rejonami świata (w tym wypadku państwami postkomunistycznymi lub postkolonialnymi), szczególnie w odniesieniu do kwestii samoidentyfikacji i modeli budowania swojej tożsamości, ujawniają m.in. ukierunkowane na przeszłość badania etnograficzne (oral history), w których przedmiotem analizy są właśnie różne (często sprzeczne) strategie tożsamościowe oraz sposoby komponowania narracji o swoim życiu przez osoby nienormatywne. Dalsze badania w tym zakresie, w szczególności podejmujące temat głosów dotąd nie(do)reprezentowanych - nieheteronormatywnych kobiet, osób transseksualnych, czy osób nieidentyfikujących się z takimi kategoriami tożsamościowymi jak "gej" czy "lesbijka" - pozwoli dotrzeć do kolejnych kontekstów odsłaniających być może odrębność polskiej historii kształtowania się tożsamości nienormatywnych. Podobnie jest w przypadku omówionych tu narracji o życiu homoseksualnych mężczyzn z okresu PRL, których indywidualne relacje - oraz język, za pomocą którego opowiadają o swoim prywatnym doświadczeniu „inności” - w znacznym stopniu różnią się od współczesnego, emancypacyjnego (aktywistycznego) modelu tożsamości gejowskiej realizowanej w ramach zachodniej identity politics. Uchwycenie różnicy w postrzeganiu swojej tożsamości pomiędzy różnymi pokoleniami osób nieheteronormatywnych wydaje się zatem służyć podważeniu dominacji zachodniego modelu „upolityczniania” tożsamości gejowskiej, w ramach którego kraje byłego bloku wschodniego postrzegane są jako „zapóźnione” i zmuszone do "doganiania” państw zachodnich. Rekonstrukcja tego, jak kształtował się - nawet w ściśle ograniczonych ramach (np. klasowych) zarysowany tu antyesencjalistyczny (queerowy) dyskurs dotyczący ekspresji nienormatywnej seksualności w okresie poprzedzającym wskazane przez Warkockiego fazy emancypacji może również przyczynić się do zrozumienia różnic w strategiach przyjmowanych przez różne grupy i osoby wchodzące w skład dzisiejszej społeczności LGBTQ w Polsce.

\section{Podziękowania}

Artykuł powstał w ramach projektu "Cruising the 1970s: Unearthing Pre-HIV/AIDS Queer Sexual Cultures" (CRUSEV) finansowanego ze środków HERA Joint Research Programme 3 "Uses of the Past"

${ }^{9} \mathrm{O}$ podtrzymywaniu fałszywej dychotomii pomiędzy „Zachodem” a państwami postkomunistycznymi w kontekście analizy dyskursów emancypacyjnych i tożsamościowych krytycznie pisali m.in. Robert Kulpa i Joanna Mizielińska w redagowanym przez siebie tomie De-centring Western sexualities: Central and Eastern European perspectives (2011). 
przy współfinansowaniu ze strony AHRC, BMBF via DLR-PT, MINECO, NCN oraz Komisji Europejskiej w ramach programu Horizon 2020.

\section{Bibliografia}

Biedroń, Robert. 2010. Historia homoseksualności w Polsce. W: (red.) Abramowicz, Marta, Biedroń, Robert, Kochanowski, Jacek. Queer Studies. Podręcznik kursu. Warszawa: Kampania Przeciw Homofobii, s. 57-95.

Donham, Donald L. 2012. Wyzwalanie Republiki Południowej Afryki. Unowocześnianie seksu pomiędzy mężczyznami. W: (red.) Kościańska, Agnieszka. Antropologia seksualności. Teoria, etnografia, zastosowanie. Warszawa: Wydawnictwo Uniwersytetu Warszawskiego, s. 383-402.

Hall, Timothy McCajor. 2009. Stories from the Second World: Narratives of Sexual Identity Across Three Generations of Czech Men who have Sex with Men. W: (red. Cohler, Bertram J. Hammack, Phillip L. The Story of Sexual Identity: Narrative Perspectives on the Gay and Lesbian Life Course. New York: Oxford University Press, s. 77-130.

Janion, Ludmiła. 2017. Global Gay and Soviet Queen: Polish Transformation and Discourses of Homosexual Gender Variance. W: "Central Europe" 15 (1-2), s. 35-44.

Kościańska, Agnieszka. 2017. Zobaczyć łosia. Historia polskiej edukacji seksualnej od pierwszej lekcji do internetu. Wołowiec: Czarne.

Krzyszpień, Jerzy. 2010. Język i emancypacja LGBT: uwagi praktyczne. W: (red.) Abramowicz, Marta, Biedroń, Robert, Kochanowski, Jacek. Queer Studies. Podręcznik kursu. Warszawa: Kampania Przeciw Homofobii, s. 139-146.

Kulpa, Robert i Joanna Mizielińska (red.). 2011. De-centring Western Sexualities: Central and Eastern European Perspectives. Farnham: Ashgate.

Kurpios, Paweł. 2003. Poszukiwani, poszukiwane. Geje i lesbijki a rzeczywistość PRL. W: „Zeszyty Kulturoznawcze" 1, s. 27-34.

Lis, Bartek. 2009. Seksualne obywatelstwo i nieheteronormatywne doświadczanie przestrzeni. W: "Kultura Popularna” 2, s. 104-112.

Lis, Bartek. 2015. Gejowskie (nie)męskości. Normy ptciowe a strategie tożsamościowe gejów. Gdańsk: Wydawnictwo Naukowe Katedra.

Morawska, Karolina. 2019. "Którego serdeczna, uczciwa przyjaźń będzie motorem mojego życia...” anonse towarzyskie w "Relaksie" z lat 1984 - 1988. "InterAlia” 14, s. 51-72.

Nowak Tomasz Łukasz. 2016. Gdzie jest gej? O (nazwach) przestrzeni w pierwszych polskich pismach gejowskich. W: „Dziennikarstwo i media” 7, s. 173-185.

Ryziński, Remigiusz. 2017. Foucault w Warszawie. Warszawa: Dowody na Istnienie.

Szulc, Łukasz. 2018. Transnational Homosexuals in Communist Poland. Cross-Border Flows in Gay and Lesbian Magazines. Palgrave Macmillan.

Tomasik, Krzysztof. 2012. Gejerel. Warszawa: Wydawnictwo Krytyki Politycznej.

Warkocki, Błażej. 2014. Trzy fale emancypacji homoseksualnej w Polsce. W: „Porównania” 15, s. 121 132.

Welenc, Marcin. 2018. Coming out. Studia nad homoseksualnościa męską. Gdańsk: Wydawnictwo Naukowe Katedra. 
Witkowski, Michał. 2014. Lubiewo bez cenzury. Warszawa: Świat Książki.

\section{"What was there to admit to, if homosexuality didn't exist?" Pink language in the memory narratives about male homosexuality in the People's Republic of Poland}

The article is based on research material consisting of ethnographic interviews conducted as part of the CRUSEV international research project. The author analyzes chosen narratives from the perspective of the language which the interview partners use to reconstruct their memories from the People's Republic of Poland, a period when homosexuality was a taboo subject and was scarcely present in public discourse. The author focuses on several aspects of these memory narratives: the self-identification of the interviewees, the issue of coming out to closest family members, and the specific code or "pink language" used by the urban homosexual communities. The author argues that the way in which interviewees construct their life narratives (e.g. allusiveness, playfulness) reflects not only on the specificity of non-normative life in the People's Republic, but also on the different strategies of constructing pre-emancipatory gay identities.

Keywords: homosexuality, oral history, biography, memory, language 